\title{
Are Stock Prices a Random Walk? An Empirical Evidence of Asian Stock Markets
}

\author{
Seema Rehman ${ }^{1}$, Imran Umer Chhapra ${ }^{2}$, Muhammad Kashif ${ }^{3}$, Raja Rehan ${ }^{4}$
}

\begin{abstract}
Investigating if the market is efficient is an old issue as market efficiency is imperative for channeling investments to best-valued projects and its importance endures. There is contradictory evidence in the literature provided by empirical researches. The primary purpose of this research has been to find out whether share prices are a random walk process by applying multiple unit root tests, Runs Test and newly developed State Space Model. The empirical findings of the study provide sufficient evidence that the stock prices of KSE 100 Index, S \& P BSE 500 Index, and CSE All Share Index is not a random walk process and are thus weak form inefficient hypothesis. In this study, the concept of the random walk is examined considering only the stock markets while bypassing the other asset markets. This research supply exciting facts about independent samples from Pakistan, India, and Bangladesh and complement the existing literature on emerging markets.
\end{abstract}

Keywords: random walk, efficient market hypothesis, state space model

\begin{abstract}
Abstrak. Penyelidikan apakah pasar efisien adalah suatu isu lama karena efisiensi pasar sangat penting untuk menyalurkan investasi ke proyek-proyek bernilai terbaik dan pentingnya bertahan. Terdapat bukti yang bertentangan dalam literatur yang disediakan oleh penelitian empiris. Tujuan utama dari penelitian ini adalah untuk mengetahui apakah harga saham merupakan proses random walk dengan menerapkan beberapa tes root unit, Runs Test dan State Space Model yang baru dikembangkan. Temuan empiris dari penelitian ini memberikan bukti yang cukup bahwa harga saham KSE 100 Index, S \& P BSE 500 Index dan CSE All Share Index bukanlah proses random walk dan dengan demikian merupakan bentuk hipotesis yang kurang efisien. Dalam penelitian ini, konsep random walk diperiksa hanya mempertimbangkan pasar saham sementara melewati pasar aset lainnya. Penelitian ini memberikan fakta menarik tentang sampel independen dari Pakistan, India dan Bangladesh dan melengkapi literatur yang ada di pasar negara berkembang.
\end{abstract}

Kata kunci: random walk, hipotesis pasar efisien, state space model

\section{How to Cite:}

Rehman, S., Kashif, M., Chhapra, I. U., \& Rehan, R. (2018). Are Stock Prices a Random Walk? An Empirical Evidence of Asian Stock Market. Etikonomi: Jurnal Ekonomi. Vol. 17 (2): 237 - 252. doi: http//dx.doi.org/10.15408/etk.v17i2.7102. 


\section{Introduction}

Market efficiency is a fundamental concept in the finance literature. For a long time, research scholars and economists have explored the efficiency concept related to capital markets. There is contradictory evidence in the literature regarding the efficient market hypothesis (EMH), some researches support it while others reject it. How it all began and the way the researches evolved during the recent years is fundamental. The changes in the economic and financial conditions of the market system and the emergence of new statistical techniques, continually call for the testing of the market efficiency empirically. Thus this study tries to find the efficiency of Asian stock markets by taking current data and modern approaches.

The long run time series properties of share prices have caught substantive attention from analysts particularly in investigating if the share prices can categorize as a unit root process or a mean reversion process (Chaudhuri and Wu, 2003). The uncertainties involved in predicting stock movement make it difficult for investors and analysts to forecast stock price index (Patel et al., 2015). Three categories or market efficiency levels are identified by researchers in analyzing market efficiency outlined by Fama (1970), weak form, semi-strong form, and reliable form necessary levels of market efficiency.

As Malkiel (2003) put it,

The random walk [states] that if the flow of information is unimpeded and . . immediately reflected in stock prices, then tomorrow's price change will only reflect tomorrow's news and will be independent of price changes today. But news is by definition unpredictable, and, thus, resulting price changes must be unpredictable and random. As a result prices fully reflect all known information, and even uninformed investors buying a diversified portfolio at the tableau of prices given by the market will obtain a rate of return as generous as that achieved by the experts.

The random walk theory implies that stock price changes (difference in the cost of a security from one period to another) retain the same probability distribution and are independent of one another; therefore the past movement of a stock price cannot be employed to forecast its future movement (Lean and Smyth, 2007).

Apart from its profit-making implications, the EMH has numerous implications for investors and regulators. Primarily a stock market is concerned with efficiently allocating resources in an economic system by channeling savings into valuable investments. If a market is efficient and traders have full information of all firms (reflected by the market price of the corresponding share), then the investment will be allocated by the stock market to the most efficient opportunity and trading activities can take place without much uncertainty. However, if the market is not efficient that is, stock prices do not reflect all available information, then the resource allocating efficiency turn questionable suggesting a more prominent role for regulatory bodies in protecting the individual investors (Lean et al., 2015).

The primary research questions are what are the implications of the random walk behavior on the investors and regulatory bodies and are the KSE 100 Index, S \& P BSE 500 Index and CSE All Share Index a random walk? 
This study extends not only the existing literature about three emerging economies of Pakistan, India, and Bangladesh but is also advantageous to people who use all available information to devise their investing strategies. The following part furnishes a detailed literature review on the topic. The next section gives information about the research methodology employed in the study providing details about data sources and statistical techniques. Fourth part pertains to research findings. The last section covers conclusions and areas for future studies.

\section{Method}

The time series data used in the study covers the period from 30th June 2005 to 30th June 2017 presenting daily returns of KSE 100 Index, S \& P BSE 500 Index and CSE All Share Index. The data has obtained from Thomson Reuters DataStream and the official website of Pakistan Stock Exchange. The current period returns act as the dependent variable and the lagged returns for all other periods as independent variables for several statistical models applied to the data. Several methods have been used to test the financial markets efficiency (Lim and Brooks, 2011). Investigating the presence of unit root in equity prices is one of the popularized methods for checking EMH in financial markets. The statistical models include stationarity tests of DF, ADF, Phillip Perron, KPSS; Runs Test for validating random walk hypothesis; and State Space Model for detecting any persistent patterns in the data.

The Dickey and Fuller Model

$\Delta r_{t}=\psi r_{t-1}+u_{t}$

Where $\psi=\phi-1$

The Augmented Dickey and Fuller Model

$\Delta r_{t}=\alpha+\delta r_{t-1}+\sum_{j=1}^{q} \delta_{j} \Delta r_{t-1}+\varepsilon_{t}$

$\Delta r_{t}=\alpha+\beta_{t}+\delta r_{t-1}+\sum_{j=1}^{q} \delta_{j} \Delta r_{t-1}+\varepsilon_{t}$

Where $r_{t}$ are returns and $\varepsilon_{t}$ is white noise.

Phillip Perron

$\Delta r_{t}=\alpha r_{t-1}+x_{t}^{n} \delta+\varepsilon_{t}$

Where $\alpha=p-1$

KPSS Test

$x_{t}: r_{t}=x_{t}^{n} \delta+u_{t}$

The most commonly used test for checking random walk hypothesis is Run Test. It is a nonparametric test and doesn't require the condition of normal distribution for the data. To execute this test supposes $n_{a}$ and $n_{b}$ present observations before and after the sample mean respectively and $r$ are the frequency has runs with $n=n_{a}+n_{b}$ (Mishra, 2013).

$Z(r)=\frac{r-E(r)}{\sigma(r)}$

The following formula could then be used to calculate the expected number of runs. 


$$
E(r)=\frac{n+2 n_{a} n_{b}}{n}
$$

The standard error is presented as.

$$
\sigma(r)=\left[\frac{2 n_{a} n_{b}\left(2 n_{a} n_{b}-n\right)}{n^{2}(n-1)}\right]^{\frac{1}{2}}
$$

Runs test accounts for not only outliers but also structural breaks in the data.

In this paper, the predictability of stock return is not just the major issue, thus the State Space Model has also been utilized as it encompasses an approach for extracting signals in the sample data and at the same time it also incorporates the non-normal and time varying volatile nature of stock returns as well existed in the literature. A State Space Model generally contains two random constituents $r_{t}$ and $s_{t}$ which evolve and relate to each other by the following equations.

$$
\begin{aligned}
& r_{t}=\alpha+s_{t}+\varepsilon_{t} \\
& s_{t}=\mu s_{t-1}+v_{t}
\end{aligned}
$$

Where $S_{t}$ represents the state at time period $t, \alpha$ and $\mu$ are known matrices that may depend on time. ${ }^{\varepsilon_{t}}$ is white noise with 0 mean and constant variance $\sigma_{t}^{2} . v_{t}$ represents a vector consisting of white noise processes, where each process is uncorrelated with $\varepsilon_{t}$. In this model, equation 9 is called the Observation Equation and equation 10 is known as the State or System Equation. The stock price indices KSE 100 Index of Pakistan, S \& P BSE 500 Index of India and CSE All Share Index of Bangladesh are first converted into returns for running statistical tests.

Continuously compounded returns, $r_{t}=100 \% * \operatorname{In}\left(P_{t} / P_{t-1}\right)$

Where $r_{t}$ is the continuously compounded return related to time $t$, stock price at time $t$ is denoted by $P_{t}$ and $I n$ is the natural logarithm.

\section{Result and Discussion}

Descriptive statistics show that the daily returns series of KSE 100 Index, S \& P BSE 500 Index and CSE All Share Index are leptokurtic that is having higher peaks and thick tails showing high volatility in the daily returns distributions of these indices. Moreover, Jarque Bera test tells us that all the three series are not normal.

Table 1. Dicky and Fuller Test

\begin{tabular}{ccc}
\hline Return Index & DF Statistics with Intercept & $\begin{array}{c}\text { DF Statistics with Trend and } \\
\text { Intercept }\end{array}$ \\
\hline KSE 100 Index returns & -47.26 & -47.56 \\
S \& P BSE 500 Index & -8.95 & -50.61 \\
CSE All Share Index & -3.49 & -6.12 \\
\hline
\end{tabular}


Both the models of inclusion of intercept and the least restrictive model with the inclusion of trend and intercept terms are used while executing the stationarity tests of DF, ADF, Phillip Perron and KPSS. In type of models, the intercept and the trend \& intercept terms are significant with the p-values of less than 0.05 that means at $5 \%$ level of significance.

Table 2. Augmented Dicky and Fuller Test

\begin{tabular}{ccc}
\hline Return Index & ADF Statistics with Intercept & $\begin{array}{c}\text { ADF Statistics with Trend and } \\
\text { Intercept }\end{array}$ \\
\hline KSE 100 Index returns & -47.77 & -47.77 \\
S \& P BSE 500 Index & -51.47 & -51.46 \\
CSE All Share Index & -55.17 & -55.20 \\
\hline
\end{tabular}

The Dicky and Fuller Test's absolute values are higher than the MacKinnon critical values, the series of KSE 100 Index returns, S \& P BSE 500 Index returns, and CSE All Share Index returns are stationary, hence following an asymptotic distribution. As the Augmented Dicky and Fuller Test's absolute values are higher than the critical values, the series of KSE 100 Index returns, S \& P BSE 500 Index returns and CSE All Share Index returns are stationary, hence following an asymptotic distribution.

Table 3. Phillip Perron Test

\begin{tabular}{ccc}
\hline Return Index & Phillip Perron Statistics with Intercept & $\begin{array}{c}\text { Phillip Perron Statistics with } \\
\text { Trend and Intercept }\end{array}$ \\
\hline KSE 100 Index returns & -48.05 & -48.05 \\
S \& P BSE 500 Index & -51.48 & -51.47 \\
CSE All Share Index & -55.17 & -55.22 \\
\hline
\end{tabular}

The Phillip Perron test further strengthen the ADF test that the return series of KSE 100 Index returns, S \& P BSE 500 Index returns and CSE All Share Index returns do not have a unit root by rejecting the null hypothesis.

Table 4. KPSS Test

\begin{tabular}{ccc}
\hline Return Index & KPSS Statistics with Intercept & $\begin{array}{c}\text { KPSS Statistics with Trend and } \\
\text { Intercept }\end{array}$ \\
\hline KSE 100 Index returns & 0.16 & 0.09 \\
S \& P BSE 500 Index & 0.08 & 0.07 \\
CSE All Share Index & 0.43 & 0.13 \\
\hline
\end{tabular}


In the KPSS test we accept the null hypothesis of stationarity. Such kind of behavior shows the predictability of the stock market. According to Perron (1989), one disadvantage of using both the traditional unit root tests of ADF and Phillip Perron is that they have low power for rejecting the null hypothesis of series having a unit root if there are structural breaks in the data. Whereas if structural breaks are ignore in the data, the KPSS test statistics is biased in favoring to reject the null hypothesis that is of stationarity of series in this case.

Table 5. Runs Test with Mean Base

\begin{tabular}{cccc}
\hline Run Test & KSE 100 Index returns & $\begin{array}{c}\text { S \& P BSE 500 Index } \\
\text { returns }\end{array}$ & $\begin{array}{c}\text { CSE All Share Index } \\
\text { returns }\end{array}$ \\
\hline Test Value & 0.00 & 0.00 & 0.00 \\
Cases $<$ Test Value & 1636 & 1543 & 1725 \\
Cases $\geq$ Test Value & 1495 & 1588 & 1406 \\
Total Cases & 3131 & 3131 & 3131 \\
Number of Runs & 1366 & 1463 & 1310 \\
Z & -7.07 & -3.69 & -8.68 \\
Asymp. Sig. (2-tailed) & 0.00 & 0.00 & 0.00 \\
\hline
\end{tabular}

Runs Test is performed to check the randomness of the market. The Runs Test does not make any finite variance assumption, as it is a non-parametric test, therefore, is preferred while testing random walk hypothesis for stock markets. Table 5 and Table 6 summarize the output of the Runs Test for KSE 100 Index, S \& P BSE 500 Index and CSE All Share Index.

Table 6. Runs Test with Median Base

\begin{tabular}{cccc}
\hline Run Test & KSE 100 Index returns & $\begin{array}{c}\text { S \& P BSE 500 Index } \\
\text { returns }\end{array}$ & $\begin{array}{c}\text { CSE All Share Index } \\
\text { returns }\end{array}$ \\
\hline Test Value & -5.75 & 1.40 & -2.87 \\
Cases $<$ Test Value & 1565 & 1565 & 1562 \\
Cases $\geq$ Test Value & 1566 & 1566 & 1569 \\
Total Cases & 3131 & 3131 & 3131 \\
Number of Runs & 1370 & 1459 & 1332 \\
Z & -7.03 & -3.84 & -8.38 \\
Asymp. Sig. (2-tailed) & 0.00 & 0.00 & 0.00 \\
\hline
\end{tabular}

The values of $Z$ for three indices are more than the critical value of -1.96 with significant p-values suggesting too many runs in the sample indicating that there are negative serial correlation or autocorrelation. Therefore the null hypotheses that the KSE 100 Index daily 
returns, S \& P BSE 500 Index daily returns and CSE All Share Index daily returns are a random walk are undoubtedly rejected. The Runs Test shows that Pakistan Stock Exchange, National Stock Exchange of India and Chittagong Stock Exchange are unquestionably inefficient in a weak form.

Table 7. Kalman Filter State Space Model Results for KSE 100 Index

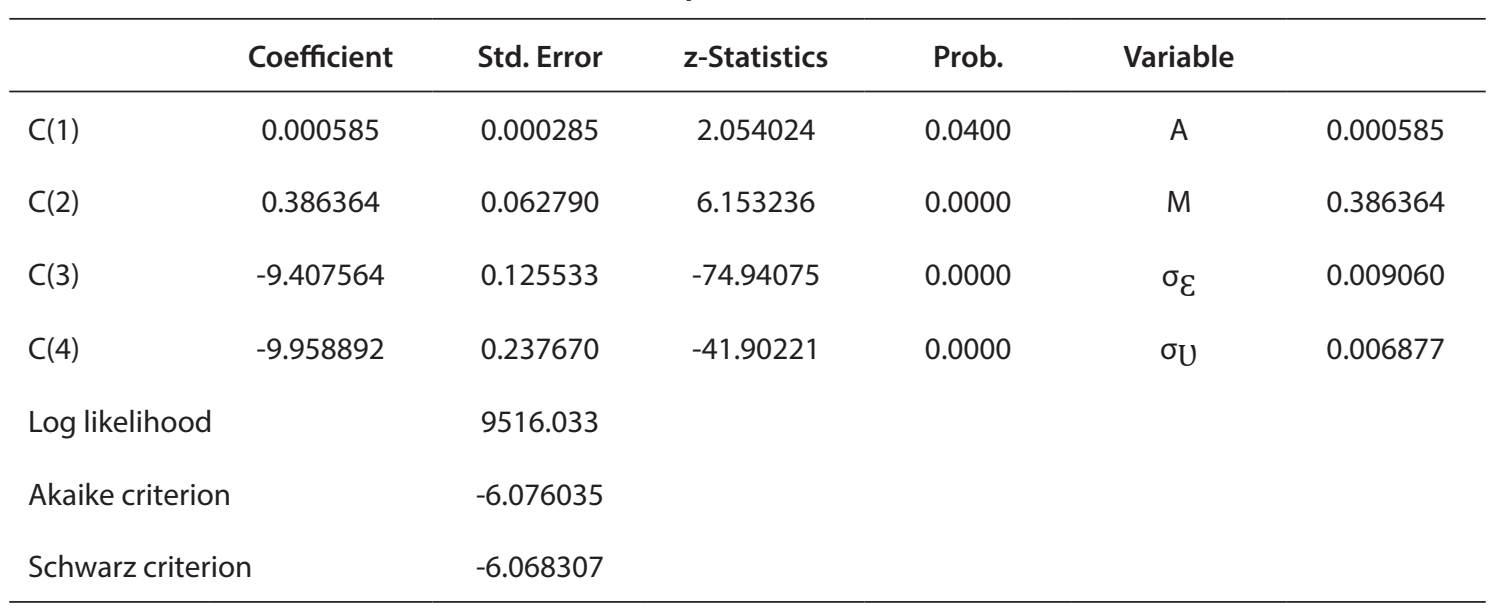

Table 7, 8, and 9 show the general space-state model of a random walk for the three indices. The term $\mathrm{C}(1)$ represents the drift, $\mathrm{C}(2)$ represent the coefficient of the lag of unobserved state. $\mathrm{C}(3)$ and $\mathrm{C}(4)$ represents the variance of error terms of the signal and state equation respectively.

The probability values for all the variances $\sigma \mathcal{E}$ of the error terms of the signal equation for three returns series of KSE 100 Index, S \& P BSE 500 Index and CSE All Share Index are less than 0.05 showing the presence of significant predictable component based on LR test statistics. There is statistically significant evidence of the existence of persistent constituent in the daily returns of KSE 100 Index, S \& P BSE 500 Index, and CSE All Share Index. So in Pakistani, Indian and Bangladeshi equity markets, there is a possibility of realizing abnormal returns by using historical data, trading volume and other information related to the market.

Table 8. Kalman Filter State Space Model Results for S \& P BSE 500 Index

\begin{tabular}{|c|c|c|c|c|c|c|}
\hline & Coefficient & Std. Error & z-Statistics & Prob. & Variable & \\
\hline$C(1)$ & 0.000481 & 0.000286 & 1.681250 & 0.0927 & $A$ & 0.000481 \\
\hline$C(2)$ & 0.185087 & 0.120542 & 1.535458 & 0.1247 & M & 0.185087 \\
\hline$C(3)$ & -9.141304 & 0.554866 & -16.47481 & 0.0000 & $\sigma_{\mathcal{E}}$ & 0.010351 \\
\hline$C(4)$ & -9.385496 & 0.728895 & -12.87634 & 0.0000 & $\sigma_{U}$ & 0.009161 \\
\hline \multicolumn{2}{|c|}{ Log likelihood } & 8949.138 & & & & \\
\hline \multicolumn{2}{|c|}{ Akaike criterion } & -5.713918 & & & & \\
\hline \multicolumn{2}{|c|}{ Schwarz criterion } & -5.706190 & & & & \\
\hline
\end{tabular}


The results report robust indicators beneficial for people interested in investing, hedging, arbitraging and speculating. Also, the study provides relevant details for fundamental and technical analysts concerning investment in the financial markets of Pakistan, India, and Bangladesh.

Table 9. Kalman Filter State Space Model Results for CSE All Share Index

\begin{tabular}{|c|c|c|c|c|c|c|}
\hline & Coefficient & Std. Error & z-Statistics & Prob. & Variable & \\
\hline$C(1)$ & 0.000525 & 0.000329 & 1.595706 & 0.1106 & $a$ & 0.000525 \\
\hline$C(2)$ & 0.931552 & 0.030929 & 30.11880 & 0.0000 & $\mu$ & 0.931552 \\
\hline$C(3)$ & -8.745367 & 0.010889 & -803.1713 & 0.0000 & $\sigma_{\varepsilon}$ & 0.012617 \\
\hline$C(4)$ & -14.49074 & 0.595764 & -24.32297 & 0.0000 & $\sigma_{U}$ & 0.000713 \\
\hline Log likelihood & & 9215.559 & & & & \\
\hline Akaike criterion & & -5.884100 & & & & \\
\hline Schwarz criterion & & -5.876372 & & & & \\
\hline
\end{tabular}

According to Jensen (1978), there have been certain proofs of stock prices behaving strangely where price predictability is possible by observing patterns and trends. Thus, analyzing the notion of EMH as well as the processes and empirical tests is significantly essential (Ahmad et al., 2006). Beginning with the influential paper by Fama (1970) on several types of market efficiencies, some studies have focused on the problem, "Is stock market efficient?" One reason for not achieving a consensus may be accredited to either the use of different time periods for different stock markets with varying progression levels or to the employment of different techniques that have many restrictive assumptions.

Recent researches also incorporate the crucial role of nonlinearity of stock prices in determining stock market behavior (Gozbasi et al., 2014). Furthermore, the degree of stock market efficiency has attracted substantive debate. According to Lo (2004) adaptive market hypothesis, fresh evidence has been provided by new studies empirically that market efficiency concerning EMH is dynamic, and significantly context dependent and that market could be outperformed as abnormal returns can come up occasionally as a response to changing market circumstances (Neely et al., 2009; Lim and Brooks, 2011; Kim et al., 2011). Kim et al., (2011) investigated EMH for US equity market by taking data over the period of 100 years and showed empirically that the predictable nature of returns varies over time and is dependent upon the existing conditions of the market and economy. Most of the objection on EMH based on the speediness of information reaching the market traders (Naseer and Bin Tariq, 2015).

Emerging markets of less developed countries are believed to be less efficient than the stock markets of developed countries. The developing markets characterized as shallow with high turnover and high growth potential. However, the participants in such markets are not as well informed as of developed markets leading to their irrational behavior. Some major causes 
of low progress in developing markets are the low capital market development, transaction costs, the absence of appropriate information, costly ways to acquire fresh information and a higher level of future uncertainty (Mustafa and Ahmed, 2013). Also, speculative activities, insufficient data, lack of structured profiles, substandard rules, the absence of supervision and inability of administrative bodies in implicating existent regulations are some other reasons for inefficiency in emerging markets.

Lim et al. (2008) investigated the impact of the financial crisis of 1997 on eight Asian Equity markets' efficiency by using the statistical technique of rolling bi-correlation. The findings revealed a negative impact of the crises on most of the markets' efficiency, however; the crisis affected the stock market of Hong Kong the most. Tiwari and Kyophilavong (2014) examined the BRICS stock indices for testing the random walk hypothesis. The findings provided sufficient evidence that rejected the null hypothesis of a sample having unit root for entire BRICS countries except for Russian Federation thus providing evidence for the predictable nature of equity markets in these countries. Using the variance ratio statistic can be beneficial while testing the EMH against exciting alternatives, particularly those hypotheses related to mean-reverting model (Deo and Richardson, 2003). Abraham et al. (2002) applied the variance ratio analysis and the runs test to check the random walk characteristics and weak form efficiency of three gulf markets of Saudi Arabia, Kuwait and Bahrain by using the monthly data for the period between 1992 and 1998. They used the accurate underlying indices by employing the Beveridge and Nelson (1981) decomposition to mitigate the effects of infrequent trading. The results implied weak form efficiency except for Kuwait stock market. Adhikari and Agrawal (2014) used a new hybrid methodology that combined the Random Walk, Feedforward Artificial Neural Network FANN and Elman Artificial Neural Network EANN models for forecasting financial data that improved accuracies.

Lee et al. (2010) investigated EMH for equity markets through various economic developmental stages for the period between Jan 1999 and May 2007 by using unit root tests for panel data incorporating one or more structural breaks in the sample. By accounting for cross-sectional dependency and over sighting limited data bias, the data appeared non-random for twenty-six developing and thirty two developed economies that are inconsistent with the EMH. Aue et al. (2009) investigated procedures to detect structural breaks in the original data and assessed if the break is due to a shifting mean, random walk processor switching of errors under unchanged means from stationary to difference stationary characteristics. Su et al. (2015) used two advanced level tests that account for heteroscedasticity, the automatic Box-Pierce Qk test by Escanciano and Lobato (2009) and generalised Andrews-Ploberger test by Nankervis and Savin (2010) for examining the efficiency of sixteen Asian stock markets comprising of five developed, nine emergent and two frontier economies. The writers demonstrated the efficiency of all developed economies whereas the inefficiency of the frontier economies and mixed findings for emerging ones. Moreover, they concluded that the degree to which these markets are efficient changes over time.

The study of Righi and Ceretta (2011) investigated weak form efficiency of stock markets in the US and Latin America using daily data from 2005 to 2010 applying variance ratio test. Results provided evidence for Latin markets as weak form efficient. However, the 
hypothesis of a random walk for the US market got rejected during the sub-prime crisis. Some of the studies that found evidence in favor of the random walk hypothesis are by Alexeev and Tapon (2011) for the Toronto Stock Exchange, Narayan (2005) for Australian and New Zealand stock prices. Hasanov and Omagy (2007) in Eastern European republics and Narayan \& Smyth (2006) in fifteen European securities exchanges provided evidence in support of weak form efficiency. Robinson (2005) checked that the Jamaica Stock Exchange is not weak form efficient for at least 65 percent listed stock by using autocorrelation and runs tests.

In the Palestinian stock market, Awad and Daraghma (2009) proved a random walk hypothesis. Similarly, Oskooe et al. (2010) conducted their study for Iranian securities market found evidence in favor of EMH. A few other researches that concluded the equity price behavior inconsistent with EMH are Buguk and Brorsen (2003) for the Istanbul Stock Exchange; Qian et al (2008) for Chinese SSEC index; Cheung and Coutts (2001) for Hong Kong Stock Exchange; Narayan and Smyth (2004; 2005) for South Korean and OECD stock markets; Marashdeh and Shrestha (2008) in United Arab Emirates; Ozdemir (2008) in Turkish securities market; and Munir and Mansur (2009) in Malaysia. Bariviera (2011) and Lin et al. (2011) examined the Thai stock market and Shanghai stock market respectively and proved the randomness of equity price in both the markets. Lai et al. (2002) investigated if the stock returns are predictable by using technical trading rules for daily data on the Kuala Lumpur Stock Exchange including both bull and bear times. Nwidobie (2014) provided evidence that the stocks of listed firms on the Nigerian Stock Exchange are not a random walk. The writer demonstrated that this finding is following Granger's (1992) that infrequently traded equities may not follow a random walk.

Many researchers have administered researches on Pakistan stock market to test weakform EMH. Mustafa and Nishat (2007) emphasized that Pakistani equity market is weak form efficient by employing daily, weekly and monthly observations. They incorporated thinly trade and non-linear properties for weekly and monthly equity observations to detect efficiency. However, Haider and Nishat (2009) demonstrated inefficiency for Pakistan market contradicting the prior result of efficiency. Tahir (2011) considered the data for twenty listed firms on PSX for the period between 2000 and 2009 and rejected weak form EMH by using technical analysis. Similarly, Haque et al. (2011) could not prove weak form EMH by taking weekly observations of KSE 100 Index over ten year period from 2000 to 2010 . Their results provided evidence of trends in historical prices that could be useful for predicting future returns. Kiani (2006) working on the same line to predict the market, reported inefficiency by employing non-Gaussian state space modeling on the KSE 100 Index. Sultan et al. (2013) used the period between 2005 and 2010 for comparing weak form EMH on Pakistani and Kuwaiti stock markets. They employed ADF and autocorrelation tests to assert the evidence of inefficiency for both exchanges. Rehman and Qamar (2014) emphasized market inefficiency is employing ACF, ADF and runs test, taking daily data of KSE 100 Index over the period of 2 years from 2009 to 2010. The study of Hameed et al. (2006) found persistent volatility clustering in stock returns while investigating weak-form EMH that rejected on Pakistani stock market. On 
the contrary, Haroon and Shah (2013) found supporting results (strong serial correlation) of the Monday effect while rejecting weak-form EMH on KSE. Khan et al. (2016) rejected the random walk hypothesis by showing that investors can generate abnormal profits.

In India, some studies such as Gupta and Basu (2007); Mishra and Pradhan (2009) detected market inefficiency. Mobarek et al. (2008); Khan and Huq (2013); Miah and Banik (2013) emphasized market inefficiency for Dhaka Stock Exchange by using conventional parametric and non-parametric tests including ARIMA modeling. After reviewing literature comprehensively, it had concluded that emerging market indices had been comparatively under research. Thus the findings of this research could help investors and portfolio managers in constructing investment strategies.

\section{Conclusion}

This research has investigated the issue of market efficiency in Pakistan, India, and Bangladesh located in the South Asian region. The topic selected from the gap in the literature after analyzing a comprehensive piece of literature. To date, most of the prior researches have focused on developed countries and other emerging economies ignoring the South Asian region or including the countries of this region as a part of the broader sample. The descriptive statistics indicated that all the three series of daily returns are non-normal; two of the three indices, i.e., KSE 100 Index of Pakistan, S \& P BSE 500 Index of India are negatively skewed CSE. However, All-Share Index of Bangladesh is positively skewed; and all are leptokurtic or having thick tails.

The results of the unit root tests of DF, ADF, Phillip Perron and KPSS applied to the $\log$ returns of the three series for investigating random walk hypothesis reported in Table 1, 2, 3 and 4. The findings showed that daily return data of KSE 100 Index of Pakistan, S \& P BSE 500 Index of India and CSE All Share Index of Bangladesh are predictable therefore investors have a choice of exploring arbitrage opportunities. Further, Runs Test applied for verifying the results. The analysis of the Runs Test shows significant $Z$-values at $1 \%$ significance level for all the three returns series, therefore, rejecting the null hypothesis of randomness in the data. For verifying the robustness of the empirical evidence, a newly developed State Space Model has employed. The model automatically separates the stochastic component from a variable by using complicated algorithms. The results of State Space Model for the daily returns of KSE 100 Index of Pakistan, S \& P BSE 500 Index of India and CSE All Share Index of Bangladesh reveal detection of persistence in the data suggesting the predictability of the stock returns for the three emerging markets.

Market efficiency is considered as necessary for open and transparent dissipation of information hence policymakers are concerned for making their security market as informational efficient because it acts as a barometer to assess the economic growth of a nation. As most emerging security markets demonstrated inefficiency, those economies should consider adopting laws and policies for improving efficiency to show their genuine concern to establish their markets efficiently. These economies have still to develop their equity markets for attracting individual and institutional investors. Inefficiency may result 
due to numerous reasons including the functioning of colluding brokerages, the absence of sophisticated intercommunication and technology for dissipating information, the absence of regulation implication, the existence of monopolistic patterns and insider roles. By adopting stringent policies that may help in eliminating the causes of inefficiency, emerging economies can move toward efficiency. Corporatization is one logical step for moving toward the informational efficiency of an equity market.

\section{References}

Abraham, A., Seyyed, F. J., \& Alsakran, S. A. (2002). Testing The Random Walk Behavior and Efficiency of The Gulf Stock Markets. Financial Review. Vol. 37(3): 469-480. doi: https://doi.org/10.1111/0732-8516.00008.

Adhikari, R., \& Agrawal, R. K. (2014). A Combination of Artificial Neural Network and Random Walk Models for Financial Time Series Forecasting. Neural Computing and Applications. Vol. 24(6): 1441-1449. doi: https://doi.org/10.1007/s00521-013-1386.

Ahmad, K. M., Ashraf, S., \& Ahmed, S. (2006). Testing Weak Form Efficiency For Indian Stock Markets. Economic and Political Weekly. Vol. 41(1): 49-56.

Alexeev, V., \& Tapon, F. (2011). Testing Weak Form Efficiency on The Toronto Stock Exchange. Journal of Empirical Finance. Vol. 18: 661-691.

Aue, A., Horvath, L., Huskova, M., \& Ling, S. (2009). On Distinguishing Between Random Walk and Change in The Mean Alternatives. Econometric Theory. Vol. 25(2): 411-441.

Awad, I. \& Daraghma, Z. (2009). Testing The Weak-form Efficiency of The Palestinian Securities Market. International Research Journal of Finance and Economics. Vol. 32: 7-17.

Beveridge, S., \& Nelson, C. R. (1981). A New Approach to Decomposition of Economic Time Series into Permanent and Transitory Components with Particular Attention to Measurement of The 'Business Cycle'. Journal of Monetary economics. Vol. 7(2): 151174. doi: https://doi.org/10.1016/0304-3932(81)90040-4.

Buguk, C., \& Brorsen, B.W. (2003). Testing Weak-Form Market Efficiency: Evidence from The Istanbul Stock Exchange. International Review of Financial Analysis. Vol. 12(5): 579-590. doi: https://doi.org/10.1016/S1057-5219(03)00065-6.

Chaudhuri K., \& Wu, Y. (2003). Random Walk Versus Breaking Trend in Stock Prices: Evidence from Emerging Markets. Journal of Banking and Finance. Vol. 27(4): 575592. doi: https://doi.org/10.1016/S0378-4266(01)00252-7.

Cheung, K. C., \& Coutts, J. A. (2001). A Note on Weak Form Market Efficiency in Security Prices: Evidence From The Hong Kong Stock Exchange. Applied Econometrics Letters. Vol. 8 (6): 407-410. doi: https://doi.org/10.1080/135048501750237865.

Deo, R. S. \& Richardson, M. (2003). On the Asymptotic Power of The Variance Ratio Test. Econometric Theory. Vol. 19(2): 231-239.

Escanciano, J. C. \& Lobato, I. N. (2009). Testing the Martingale Hypothesis. In: Mills, T. C., \& Patterson, K (eds). Palgrave Handbook of Econometrics. London: Palgrave Macmillan. 
Fama, E. F. (1970). Efficient Capital Markets: A Review of Theory and Empirical Work. Journal of Finance. Vol. 25(2): 383-417.

Gozbasi, O., Kucukkaplan, I., \& Nazlioglu, S. (2014). Re-examining The Turkish Stock Market Efficiency: Evidence From Nonlinear Unit Root Tests. Economic Modelling. Vol. 38: 381-384. doi: https://doi.org/10.1016/j.econmod.2014.01.021.

Granger, C. W. J. (1992). Forecasting Stock Market Prices: Lessons for Forecasters. International Journal of Forecasting. Vol. 8(1):3-13. doi: https://doi.org/10.1016/01692070(92)9003-R.

Gupta, R., \& Basu, P. K. (2007). Weak Form Efficiency in Indian Stock Markets. Journal of International Business Studies. Vol. 6(3): 57-64. doi: https://doi.org/10.19030/iber. v6 i3.3353.

Haider, S., \& Nishat, M. (2009). On Testing Efficiency of Karachi Stock Exchange Using Computational Intelligence. Proceedings of the 2009 International Conference on Information and Financial Engineering (ICIFE).

Hameed, A., Ashraf, H., \& Siddiqui, R. (2006). Stock Market Volatility and Weak-form Efficiency: Evidence from an Emerging Market. The Pakistan Development Review. Vol. 45(4): 1029-1040.

Haque, A., Liu, H. C., \& Nisa, F. U. (2011). Testing the Weak Form Efficiency of Pakistani Stock Market (2000-2010). International Journal of Economics and Financial Issues. Vol. 1(4): 153-162.

Haroon, M. A., \& Shah, N. (2013). Investigating Day-of-The-Week Effect in Stock Returns: Evidence from Karachi Stock Exchange-Pakistan. Pakistan Journal of Commerce \& Social Sciences. Vol. 7(2): 381-393.

Hasanov, M., \& Omagy, T. (2007). Are The Transition Stock Markets Efficient? Evidence From non-linear Unit Root Tests. Central Bank Review. Vol. 7(2): 1-12.

Jensen, M. C. (1978). Some Anomalous Evidence Regarding Market Efficiency. Journal of Financial Economics. Vol. 6(2/3): 95-101.

Khan, M. M. H., \& Huq, U. R. (2013). An Empirical Test of Weak Form Market Efficiency on an Emerging Market: Evidence from Dhaka Stock Exchange. Journal of Business, Vol. 34(2). Retrieved from: https://ssrn.com/abstract=2573684

Khan, M. A., Aman, Q., \& Khan, N. (2016). Technical Analysis: Concept or Reality? Pakistan Business Review. Vol. 18(3): 732-751.

Kiani, K. M. (2006). Predictability in Stock Returns in an Emerging Market: Evidence from KSE 100 stock price index. The Pakistan Development Review. Vol. 45(3): 369-381.

Kim, J. H., Shamsuddin, A., \& Lim, K. P. (2011). Stock Return Predictability and The Adaptive Markets Hypothesis: Evidence from Century-long U.S. Data. Journal of Empirical Finance. Vol. 18: 868-879.

Lai, M. M., Balachandher, K. G., \& Nor, F. M. (2002). An Examination of The Random Walk Model and Technical Trading Rules in The Malaysian Stock Market. Quarterly Journal of Business and Economics. Vol. 41(1/2): 81-104. 
Lean, H. H., \& Smyth, R. (2007). Do Asian Stock Markets Follow a Random Walk? Evidence From LM Unit Root Tests With One and Two Structural Breaks. Review of Pacific Basin Financial Markets and Policies. Vol. 10(1): 15-31.

Lean, H. H., Mishra, V., \& Smyth, R. (2015). The Relevance of Heteroskedasticity and Structural Breaks When Testing for a Random Walk With High-Frequency Financial Data: Evidence from ASEAN Stock Markets. In: Gregorious, G (eds). The Handbook of High Frequency Trading. Singapore: Elsevier.

Lee, C. C., Lee, J. D., \& Lee, C. C. (2010). Stock Prices and The Efficient Market Hypothesis: Evidence From a Panel Stationary Test With Structural Breaks. Japan and The World Economy. Vol. 22(1): 49-58.

Lim, K. P., Brooks, R. D., \&Kim, J. H. (2008). Financial Crisis and Stock Market Efficiency: Empirical Evidence from Asian Countries. International Review of Financial Analysis. Vol. 17(3): 571-591.

Lim, K. P., \& Brooks, R. D. (2011). The Evolution of Stock Market Efficiency Over Time: A Survey of The Empirical Literature. Journal of Economic Surveys. Vol. 25(1): 69-108.

Lo, A. W. (2004). The Adaptive markets hypothesis: Market efficiency from an evolutionary perspective. Journal of Portfolio Management. Vol. 30(5): 15-29.

Malkiel, B. G. (2003). A Random Walk Down Wall Street: The Time-Tested Strategy for Successful Investing. New York: W.W. Norton.

Marashdeh, H., \& Shrestha, M. (2008). Efficiency in Emerging Markets-Evidence From The Emirates Securities Market. European Journal of Economics and Finance Administration Science. Vol. 12: 143-150.

Miah, M. D., \& Banik, S. L. (2013). Measuring Weak-form of Market Efficiency: The Case of Dhaka Stock Exchange. International Journal of Financial Services Management. Vol. 6(3): 219-235.

Mishra, P. K. (2013). Random Walk Behavior: Indian Equity Market. Journal of Indian Management. Vol. 10(3): 55-66.

Mishra, P. K., \& Pradhan, B. B. (2009), Capital Market Efficiency and Financial Innovation: A Perspective Analysis. The Research Network. Vol. 4(1): 1-5.

Mobarek, A., Mollah, A. S., \& Bhuyan, R. (2008). Market Efficiency in Emerging Stock Market: Evidence From Bangladesh. Journal of Emerging Market Finance. Vol. 7(1): $17-41$.

Munir, Q., \& Mansur, K. (2009). Is Malaysian Stock Market Efficient? Evidence From Threshold Unit Root Tests. Economic Bull. Vol. 29(2): 1359-1370.

Mustafa, K., \& Nishat, M. (2007). Testing for Market Efficiency in Emerging Markets: A Case Study of the Karachi Stock Market. The Journal of Economics. Vol. 12(1): 119-140.

Mustafa, K., \& Ahmed, R. (2013). The Random Walk Model in the Karachi Stock Market: An Empirical Investigation. Journal of Economics and Sustainable Development. Vol. 4(3): 262-278. 
Nankervis, J. C., \& Savin, N. (2010). Testing for Serial Correlation: Generalized AndrewsPloberger Tests. Journal of Business and Economic Statistics. Vol. 28(2): 246-255.

Narayan, P. K. (2005). Are The Australian and New Zealand Stock Prices Nonlinear With a Unit Root? Applied Econometrics. Vol. 37: 2161-2166.

Narayan, P. K., \& Smyth, R. (2004). Is South Korea's Stock Market Efficient? Applied Econometrics Letters. Vol. 11: 707-710.

Narayan, P. K., \& Smyth, R. (2005). Are OECD Stock Prices Characterized by a Random Walk? Evidence From Sequential Trend Break and Panel Data Models. Applied Financial Econometrics. Vol. 15: 547-556.

Narayan, P. K. \& Smyth, R. (2006). Random Walk Versus Multiple Trend Breaks in Stock Prices: Evidence From 15 European Markets. Applied Financial Econometrics. Vol. 2: 1-7.

Naseer, M., \& Bin Tariq, Y. (2015). The Efficient Market Hypothesis: A Critical Review of The Literature. IUP Journal of Financial Risk Management. 12(4): 48-60.

Neely, C. J., Weller, P.A., \& Ulrich, J. (2009). The Adaptive Markets Hypothesis: Evidence From The Foreign Exchange Market. Journal of Financial and Quantitative Analysis. Vol. 44 (2): 467-488.

Nwidobie, B. M. (2014). The Random Walk Theory: An Empirical Test in the Nigerian Capital Market. Asian Economic and Financial Review. Vol. 4(12): 1840-1848.

Oskooe, S.A.P., Li, H., \& Shamsavari, A. (2010). The Random Walk Hypothesis in Emerging Stock Market. International Research Journal of Finance and Economics. Vol. 50: 51-61.

Ozdemir, Z. A. (2008). Efficient Market Hypothesis: Evidence From a Small Open-Economy. Applied Econometrics. Vol. 40: 633-641.

Patel, J., Shah, S., Thakkar, P., \& Kotecha, K. (2015). Predicting Stock and Stock Price Index Movement Using Trend Deterministic Data Preparation and Machine Learning Techniques Expert Systems with Applications. Vol. 42(1): 259-268.

Perron, P. (1989). The Great Crash, The Oil Price Shock and The Unit Root Hypothesis. Econometrica. Vol. 55: 277-302.

Qian, X. Y., Song, F. T., \& Zhou, W. X. (2008). Non-linear Behaviour of The Chinese SSEC Index With a Unit Root: Evidence From Threshold Unit Root Tests. Physica A: Statistical Mechanics and Its Applications. Vol. 387(2-3): 503-510. doi: https://doi. org/10.1016/j.physa.2007.09.029.

Rehman, S., \& Qamar, M. R. (2014). Testing Weak Form Efficiency of Capital Market: A Case of Pakistan. International Journal of Research Studies in Management. Vol. 3(1): 65-73.

Righi, A. \& Ceretta, C. (2011). RW and Variance Ratio Tests For Efficiency in The Subprime Crisis: Evidence for The U.S. and Latin Markets. International Research Journal of Finance and Economics. Vol. 72: 25-35.

Robinson, J. (2005). Stock Price Behavior in Emerging Markets: Tests for Weak Form Market Efficiency on The Jamaica Stock Exchange. Social and Economic Studies. Vol. 54(2): 51-69. 
Su, J. J., Roca, E., \& Wong, V. S. (2015). The Efficiency of Asian Stock Markets: Fresh Evidence Based on New Tests. Griffith Business School Discussion papers Finance.

Sultan, K., Madah, N. A., \& Khalid, A. (2013). Comparison Between Kuwait and Pakistan Stock Exchange Market: Testing Weak Form of Efficient Market. Academy of Contemporary Research Journal. Vol. 7(2): 59-70.

Tahir, A. (2011). Capital Market Efficiency: Evidence from Pakistan. Interdisciplinary Journal of Contemporary Research in Business. Vol. 3(8): 947-953.

Tiwari, A. K., \& Kyophilavong, P. (2014). New Evidence From The Random Walk Hypothesis for BRICS Stock Indices: a Wavelet Unit Root Test Approach. Economic Modelling. Vol. 43: 38-41. 